Published in The Journal of Family Issues (2016) 37(6):789-813

https://doi.org/10.1177/0192513X14536564

\title{
Religion and Support for Adoption by Same-Sex Couples: The Relative Effects of Religious Tradition, Practices, and Beliefs
}

\author{
Andrew L. Whitehead \\ Clemson University \\ Samuel L. Perry \\ University of Oklahoma
}

\begin{abstract}
This article examines the relative impact of religious factors on Americans' attitudes toward adoption by same-sex couples. Drawing upon national survey data, we fit logistic regression models and compute standardized logistic regression coefficients to estimate the relative net effects of religious tradition, practices, and beliefs about the Bible on support for same-sex adoption. Findings reveal that religious factors are among the strongest predictors of opposition to same-sex adoption, but that religious tradition has no significant effect on support for samesex adoption once frequency of religious practice and beliefs about the Bible are held constant. Americans who more frequently engage in practices such as religious service attendance and sacred text reading are less supportive of same-sex adoption, and compared to biblical literalists, those who believe the Bible requires interpretation, contains human error, or is a book of history/legends are all more likely to support same-sex adoption. Findings suggest that religious affiliations matter less for predicting same-sex adoption attitudes than how Americans practice and hold their faith.
\end{abstract}

Key words: same-sex adoption; same-sex families; gay and lesbian adoption; homosexuality; religion; religious tradition; beliefs; biblical literalism 
Public opinion toward gay and lesbian romantic and family relationships serves as an important barometer of future voting patterns and policy decisions regarding the legal recognition of samesex unions (Haider-Markel \& Joslyn, 2005, 2008; Olson, Cadge, \& Harrison, 2006). Landmark legislation or judicial decisions concerning family formation, particularly at the federal level, are most often precipitated by shifting opinions among the American public (Frank \& Mceneaney, 1999; Haider-Markel \& Joslyn, 2005; Rosenfeld, 2007). Consequently, investigations into what social and ideological factors tend to predict support or opposition toward same-sex relationships — and just as important, which factors matter more than others - help adumbrate the axes on which future public debates regarding same-sex families will turn.

Over the past three decades, a voluminous body of research examining the social correlates of attitudes toward same-sex romantic relationships finds that religious factors such as conservative Protestantism (vis-á-vis other religious affiliations or no affiliation) and frequent church attendance are among the most consistent predictors of opposition to same-sex sexuality, marriage, and civil unions (Adamczyk \& Pitt, 2009; Burdette, Ellison, \& Hill, 2005; HaiderMarkel \& Joslyn, 2008; Lubbers, Jaspers, and Ultee, 2009; Olson et al., 2006; Schulte \& Battle, 2004; Whitehead \& Baker, 2013; Whitehead, 2010). Far less attention, by comparison, is given to the ways in which religious factors predict Americans' attitudes toward same-sex adoption. This is a significant oversight since, to a large degree, cultural, political, and legal debates surrounding same-sex marriage are increasingly centered on the (often adopted) children of such unions (Briggs, 2012; Clarke, 2001; Rosenfeld, 2007), with religious groups at the forefront of the debate (Briggs, 2012; Wilson, 2004). Indeed, feminist historian Laura Briggs (2012) contends, "[Gay adoption] has become [the defining issue in the gay and lesbian freedom movement] — to a significant extent the question of gay marriage is centrally about the raising of 
children, for its supporters among LGBT folk, for its Christian Right opponents, and even for the judges writing decisions about it" (241).

Among the few studies that include religion measures in their analysis of support for gay and lesbian adoption, little effort is made to understand exactly how religious factors such as religious tradition, practices, and beliefs shape public opinion toward such adoptions. There is also little attempt to understand which religious factors matter most and the substantive significance of those factors relative to other relevant correlates. Rather, within the vast majority of studies that include religious predictors of support for same-sex adoption, the measures are only included as control variables in multivariate models, and thus, never receive sufficient analytical attention. Moreover, due to data limitations, the religion measures that are used are typically sparse and over-aggregated, yielding limited information about the relationship between religious life and Americans' views toward same-sex adoptive families. As a result, previous research on this topic potentially omits important nuance and insight with respect to how various dimensions of religious life, in all its complexity, shapes attitudes toward same-sex adoptions and which factors are of central importance.

The current study fills this gap in the literature on attitudes toward same-sex adoption in two important ways. First, we include a more comprehensive battery of religion measures, including religious affiliations, various religious practices, and beliefs about the Bible, in order to examine the net effects of religious factors on support for same-sex adoption, while controlling for relevant socio-demographic and ideological factors. And second, we compute standardized logistic regression coefficients in order to examine which predictors of support for same-sex adoption matter more than others. This research thus contributes to the literature on public 
opinion toward same-sex families by providing greater insight into the substantive significance of religious factors for explaining Americans' attitudes toward same-sex adoptive families.

\section{Religion and Attitudes toward Same-Sex Romantic and Family Relationships}

A growing amount of research focuses on the social and ideological correlates of support for same-sex romantic and family relationships. Drawing from a variety of data sources, researchers consistently find that persons who are more supportive of same-sex intimate relationships tend to be younger, female, non-Southern, urban, politically liberal, more educated, more exposed to diversity, less religious, and hold to the belief that homosexuality is innate, not a choice (Adamczyk \& Pitt, 2009; Burdette et al., 2005; Haider-Markel \& Joslyn, 2008; Olson et al., 2006; Perry, 2013a, 2013b; Petersen \& Donnenwerth, 1998; Whitehead, 2010).

Among these predictors of attitudes toward same-sex intimacy, religious factors - most often religious affiliation and church attendance, and less frequently, views about the Bibletend to be among the strongest predictors of attitudes toward gay civil rights both in the United States and abroad. Conservative Protestants tend to be the least supportive of same-sex romantic relationships (Andersen \& Fetner, 2008; Lubbers et al., 2009; Olson et al., 2006; Sherkat et al., 2011; Whitehead, 2013), and others have found that Muslims also tend to express opposition to such relationships (Adamczyk \& Pitt, 2010). By contrast, mainline Protestants, Jews, and the religiously unaffiliated tend to be more supportive of gay and lesbian relationships (Besen and Zicklin, 2007; Perry, 2013a, 2013b). Beyond religious affiliation, religious belief is associated with attitudes toward homosexuality as well. Individuals who hold traditional religious beliefs (e.g., "The Bible should be read literally, word for word") are consistently less supportive of homosexuality or gay civil rights (Burdette et al., 2005; Froese et al., 2008; Hill et al., 2004; Sherkat et al., 2010; Sherkat et al., 2011; Whitehead, 2010). 
The effect of church attendance—generally used as a proxy for "religiosity," religious devotion, or religious practice - also receives consistent support. A number of studies report a significant net effect of church attendance on opposition to same-sex couples and families (Andersen \& Fetner, 2008; Lubbers et al., 2009; Olson et al., 2006; Sherkat et al., 2010; Whitehead, 2010). Accounting for this effect, it is likely through regular interaction at worship services with other like-minded individuals that the plausibility structures that undergird attitudes toward various issues, like homosexuality or adoption by same-sex couples, are constructed and maintained (Berger, 1967; Petersen \& Donnenwerth, 1998). Participation in religious institutions can even influence gays and lesbians to support same-sex marriage at lower levels (Baiocco, Argalia, and Laghi, 2012). One weakness of how the majority of these studies operationalize religious behavior is their reliance on religious service attendance only. For many individuals it may be that religious service attendance is much less important while other types of religious behavior like reading sacred scriptures or devotional prayer play a primary role (Ellison, Wolfinger, and Ramos-Wada, 2013; Lubbers et al., 2009).

Some studies find that the effects of religious belief, behavior, and affiliation on attitudes toward homosexuality moderate one another (Burdette et al., 2005; Ellison \& Musick, 1993; Schulte and Battle, 2004). These findings encourage the inclusion of multiple measures of religion into each analysis to identify which aspects of religion are more closely associated with attitudes toward "morality issues" as broadly construed in public rhetoric, like homosexuality or same-sex adoption (Ellison et al., 2013; Lubbers et al., 2009). Whitehead (2010, p. 74) makes the case that when investigating attitudes toward moral issues "it is not enough to account for just one aspect of religiosity" as a measure of the effect of religion. In the current analysis multiple 
measures of religion (belief, behavior, and affiliation), in effect, triangulate the effect of religion as a whole on respondents' attitudes toward adoption by same-sex couples.

We situate the findings of prior research on religion and attitudes toward homosexuality and our analysis of religion's effect on attitudes toward same-sex adoption in the theoretical framework of structuration theory drawing on the concept of "schemas." Introduced by Giddens (1984) and elaborated by Sewell (2005), structuration theory maintains that structures denote the tendency of patterns of relations to be reproduced even when actors engaging in them are unaware of the patterns or even when they do not desire their reproduction. Structures shape actors' practices but it is also these practices that comprise and reproduce structures (Sewell, 2005). Structures, therefore, do not simply constrain behavior but also enable it; there is a duality of structure. Structures are composed of both schemas (or "rules" according to Giddens) and resources. Resources are "anything that can serve as a source of power in social interactions" (Sewell, 2005, p. 132). Schemas pattern practices and are "generalizable procedures applied in the enactment/reproduction of social life" (Sewell, 2005, p. 131). They serve as templates or rules for acting in the social world. A key quality of schemas is that they are transposable (Sewell, 2005). This transposability allows for their application to new situations and contexts.

The concept of schemas and their transposable nature helps explicate the relationship between religious belief and attitudes toward same-sex adoption, and by extension religious affiliation and same-sex adoption attitudes. Biblical literalists and Evangelical Protestants are much more likely to oppose same-sex adoption due to the schemas directing their actions toward homosexuality generally. These schemas are predicated on their interpretation of specific biblical passages that in their interpretation explicitly oppose any type of same-sex intimacy. ${ }^{1}$ The transposable nature of schemas allows biblical literalists and Evangelical Protestants to apply this 
particular schema to adoption by same-sex couples. Biblical literalists and Evangelicals also valorize the idea of the "traditional family," another schema, which is assumed to be made up of a man and wife with their biological children (Denton, 2004; Gallagher, 2002; Gallagher \& Smith, 1999; Hoffmann \& Bartkowski, 2008). Same-sex couples would obviously violate this ideal, leading Evangelicals and biblical literalists to oppose their adoption of children. The concept of schemas has proven useful in prior studies examining religion's influence on various social attitudes and outcomes (Denton, 2004; Edgell, Gerteis, and Hartmann, 2006; Hoffmann and Bartkowski, 2008; Miller and Hoffmann, 1999; Sherkat, 1998).

\section{Religion and Attitudes toward Same-Sex Adoption}

Despite the now enormous amount of research that focuses on the social correlates of support for gay and lesbian romantic relationships, relatively little research highlights support for same-sex adoption explicitly. This is likely for at least two reasons. First, the majority of legal controversy surrounding same-sex relationships is ostensibly about whether or not society should legally recognize the romantic unions of gay and lesbian couples. In this sense, same-sex adoption is viewed as a subsidiary to this broader issue. And second, researchers neglect to recognize the ways in which same-sex adoption is a different type of relationship than same-sex romantic unions, both in terms of the legal status awarded to each ${ }^{2}$ and the inherent power differentials. ${ }^{3}$ Consequently, studies of public opinion regarding gay and lesbian relationships often combine measures of support for same-sex adoption and marriage together (e.g., Schulte \& Battle, 2004; van den Akker et al., 2013). As a result, there are relatively few studies that give overt attention to the various social and ideological factors that shape Americans' views toward same-sex adoption. 
Among the few exceptions, similar to research regarding support for same-sex romantic relationships, the majority of these studies utilize church attendance and religious tradition as measures of religious life. However, the influence of religious factors is not the focus of these studies, and researchers never specify hypotheses regarding the effects of religion measures. MacLeod and his colleagues (1999) studied a group of heterosexual college students and found that more frequent church attendance was weakly associated with students believing that the adopted child of a gay male parent would benefit from custody reassignment and would suffer from sexual orientation and gender confusion if s/he remained with the gay parent. These findings washed out in multivariate models, however, likely due to the sample size $(\mathrm{N}=77)$. Using a larger sample of 364 college students, Lambert et al. (2006) found that students who attended church more often were less likely to agree that gay/lesbian parents should be allowed to adopt. Church attendance, however, was not associated with students' attitudes toward gay/lesbian foster parents, and students' self-reported importance of religion was not associated with their views regarding gay/lesbian adoption or foster parenting. Drawing upon a random sample of 413 registered voters in Florida, Ryan et al. (2004) found that Floridians who identified as Christian held a significantly lower opinion of gay and lesbian adoptive parents than persons who did not espouse Christian faith, net of other factors. Using the same data, the authors (2007) later reported that being a Christian was highly predictive of a Floridian voter opposing a boy or girl being legally adopted by a lesbian or gay parent. More recently, Averett and her colleagues (2011) studied the attitudes of 776 adoptive parents toward gay and lesbian adoption, finding membership in a Christian denomination was associated with negative attitudes toward gay and lesbian adopters among married adoptive fathers and mothers, but not adoptive 
singles, and greater religiosity (church attendance and prayer frequency) was associated with lower levels of support for gay and lesbian adoption among all adoptive parents.

Although these studies provide some empirical foundation for generating hypotheses regarding the relationship between religion and support for same-sex adoption, their findings are limited in that they are based on either convenience samples or sub-populations (college students, Florida voters, adoptive parents); their samples are rather small; and their measures of religious tradition (Christian vs. other) or religious practice are somewhat narrow. Drawing upon data from a national probability sample, Besen and Zicklin (2007) reported that persons who are “born again Christians" (broadly, Evangelical) or Roman Catholic are less likely to support gay adoption. They also found an interaction between gender and religiosity with more religious males being even less likely to support gay adoption than those who are less religious or female. Also using national-level data, Perry (2013a) included a number of religion measures to predict support for same-sex sexuality, marriage, and adoption. He found that, net of other factors, Catholics, mainline Protestants, and persons of "other" religious faiths were all more likely than Evangelical Protestants to support same-sex adoption. Black Protestants, however, were no more likely than Evangelicals to support such adoptions. He also found that persons who more frequently engaged in religious practices and strict biblical literalists were both relatively less likely to support same-sex adoption. Perry's measure of biblical literalism, however, was limited to a dichotomous measure (literalist vs. other) and thus was likely over-aggregated. Moreover, his analyses did not include the strongest predictor of support for same-sex relationships, attribution (homosexuality innate or by choice), which may have biased his findings.

\section{Hypotheses}


Building upon findings from previous research regarding the link between religious factors, homosexuality, and support for same-sex adoption specifically, we formulate the following hypotheses:

Hypothesis 1: Evangelical Protestants will be less supportive of same-sex adoption than all other religious or non-religious groups.

Hypothesis 2: Persons who more frequently engage in religious activities (including religious service attendance, prayer, and sacred text reading) will be less supportive of same-sex adoption.

Hypothesis 3: Persons who are strict biblical literalists will be less supportive of samesex adoption than persons who hold different beliefs about the Bible.

An additional strength of our study is that we are able to compare the substantive net effects of each religion measure on support for same-sex adoption. Based on previous research suggesting the primary importance of religious practices and beliefs over and against religious affiliation (Burdette et al., 2005; Ellison \& Musick, 1993; Schulte \& Battle, 2004), we predict:

Hypothesis 4: The net effects of religious practices and theological conservatism will have a stronger influence on support for same-sex adoption than religious affiliation.

\section{Data}

Data for these analyses are drawn from the third wave (2010) of the Baylor Religion Survey (BRS). The 2010 BRS is a random, national sample of 1,714 U.S. citizens administered by the Gallup Organization. The survey utilized a mixed-mode sampling design consisting of two phases. Both phases resulted in a total of 3,500 individuals screened and 2,556 possible respondents. A total of 1,714 questionnaires were returned resulting in a response rate of $49 \%$ $[1,714 / 3,500]$ among all individuals screened and a response rate of $67 \%[1,714 / 2,556]$ for those who agreed to receive a mailed survey. Previous BRS data compare favorably to other national surveys (Bader, Mencken, \& Froese, 2007) and comparisons between the 2010 BRS and the 2010 GSS are available upon request. The 2010 BRS is useful for the existing research question 
because it contains a breadth of religion measures as well as questions pertaining to attitudes toward adoption by same-sex couples and various other socio-demographic controls. The combination of these variables is not found in any other large, national random survey.

\section{Dependent Variable}

The dependent variable for this study focuses on respondents' views toward adoption by same-sex couples. The question utilized asks: "How do you feel about the morality of the following? Adoption of children by homosexual couples." ${ }^{4}$ Possible responses include "Always wrong," "Almost always wrong," "Only wrong sometimes," and "Not wrong at all." In order to predict which respondents report unequivocal support for adoption by same-sex couples, this variable was recoded such that $1=$ Not wrong at all, with all other responses recoded as 0 . Close to 40 percent of Americans declare clear support for adoption by same-sex couples (see Table 1).

\section{Independent Variables of Interest}

In order to provide a more complete picture of religion's relationship with attitudes toward same-sex adoption, we utilize a collection of religion measures that offer greater breadth and depth than those found in past research. Previous analyses measured religious affiliation using a "Christian" versus "Other" dichotomy (Averett et al., 2011; Ryan et al., 2004, 2007). However, Steensland and colleagues (2001) demonstrate that there are seven distinct religious traditions operating in the United States and individuals' affiliation with these traditions predicts their views on a number of outcomes. Their RELTRAD typology categorizes all religious groups into seven distinct categories: Evangelical Protestant, Mainline Protestant, Black Protestant, ${ }^{5}$ Catholic, Jewish, other, and no affiliation. ${ }^{6}$ This analysis follows the RELTRAD coding strategy and places all respondents into each of these categories. Because prior research consistently finds 
Evangelical Protestants the most opposed to homosexuality and gay rights, we exclude them as the contrast category.

In order to measure religious behavior this analysis includes three different measures: frequency of prayer/meditation, frequency of religious service attendance, and frequency of reading sacred scriptures. The items for reading sacred scriptures and religious service attendance range from $1=$ Never to $9=$ Several times a week. The item concerning prayer ranges from $1=$ Never to $6=$ Several times a day. A benefit of including these three measures of religious behavior is that they account for both public (religious service attendance) and private (prayer/meditation, reading sacred scriptures) activities.

In addition to religious affiliation and religious behavior, these analyses also incorporate respondents' religious beliefs. One widely used measure of religious belief is the degree to which individuals believe the Bible should be read literally. A question in the 2010 BRS asked, "Which one statement comes closest to your personal beliefs about the Bible?" Possible responses were "The Bible means exactly what it says. It should be taken literally, word-for-word, on all subjects;" "The Bible is perfectly true, but it should not be taken literally, word-for-word. We must interpret its meaning;" "The Bible contains some human error;" "The Bible is an ancient book of history and legends;" and "I don't know." We recoded this measure to create a series of dichotomous variables. Because biblical literalists tend to be most opposed to homosexuality and gay rights, we exclude them as the contrast category in the full model. We perform additional analyses (reported below) where we rotate each of the other views of the Bible into the reference category position.

\section{Control Variables}


Building upon past studies analyzing attitudes toward adoption by same-sex couples, this study includes a host of socio-demographic and ideological controls. The socio-demographic measures include age (in years), gender $(1=$ Female $)$, race $(1=$ Non-white $)$, marital status $(1=$ married), region $(1=$ South $)$, size of city $(1=$ urban $)$, educational attainment $\left(1=8^{\text {th }}\right.$ grade or less to $7=$ postgraduate $w o r k /$ degree $)$, and income $(1=\$ 10,000$ or less to $7=\$ 150,000$ or more $)$. Ideological controls include political ideology $(1=$ Extremely Liberal to $7=$ Extremely Conservative), and whether the respondent believes homosexuality is innate $(1=$ Innate).

\section{[TABLE 1 ABOUT HERE]}

\section{Methods}

Table 1 displays descriptive statistics for all of the measures utilized in this analysis. It also includes the bivariate associations between the dependent variable and each of the independent variables. Table 2 displays the various multivariate models. Due to the dichotomous coding of the dependent variable logistic regression is utilized. The first model contains only the socio-demographic factors. Model 2 includes the RELTRAD typology. Model 3 adds the religious practice measures while Model 4 includes the biblical literalism series of dichotomous variables. Models 5 and 6 include political conservatism and belief that homosexuality is innate, respectively. ${ }^{7}$ All of the variables included in the final models except religious tradition and region had missing information. Multiple imputation (MI) was used to correct for missing data (Rubin, 1987). ${ }^{8}$ To allow for the interpretation of substantive significance alongside statistical significance, standardized coefficients for the logistic regression models were estimated $\left[B_{y x}^{*}=\right.$ $\left.b_{y x}\left(s_{x} / s_{y}\right)\right]$ (Pampel, 2000). ${ }^{9}$ Table 3 displays the results of rotating the excluded category for the biblical literalism series of dichotomous variables. Doing so allows for an examination of how each distinct response differs from every other response. Table 3 does not display the 
standardized coefficients for the other religion and control variables in order to focus specifically on the relationships between the discrete categories on the biblical literalism measure. There are no substantive or statistical differences for the control and other religion variables between Model 6 displayed in Table 2 and Models 5 through 8 displayed in Table $3 .{ }^{10}$

\section{Results}

In Table 1 we find that 38.3 percent of Americans fully support adoption by same-sex couples. We also find strong correlations between the various religion measures and support for adoption by same-sex couples. Individuals who practice their religion regularly, read the bible literally, believe the bible is perfectly true but must be interpreted, or are Evangelical Protestants are much more likely to oppose adoption by same-sex couples. Those who believe the bible contains human error, believe the bible is an ancient book full of history and legend, do not know what they believe about the bible, or are unaffiliated with a religious tradition are more supportive of adoption by same-sex couples.

Table 2 presents the multivariate analyses. Model 1 contains the socio-demographic controls. Consistent with previous research, older adults, married adults, and those from the South are all less supportive of adoption by same-sex couples. Being female, living in an urban area, and increasing levels of education and income are all predictive of greater support for adoption by same-sex couples.

Model 2 includes the RELTRAD typology of religious affiliation. Net of all the effects of the relevant control variables, only the religiously unaffiliated are significantly different from Evagelical Protestants. The unaffiliated are much more likely to support adoption by same-sex couples compared to Evangelicals, with odds 2.26 times greater. The net effects of the control variables remain largely unchanged from Model 1 to Model 2. Model 3 incorporates three 
measures of religious practice. Individuals who practice their religion more frequently by reading sacred scriptures or attending religious services are much more likely to oppose same-sex adoption. Frequency of prayer, however, is not significantly associated with attitudes toward same-sex adoption. When religious behavior is included in the model the difference between the unaffiliated and Evangelicals is largely attenuated, but not completely. Controlling for public and private religious behavior does account for the statistical significance of region of the country in prior models. Identical to Models 1 and 2, age, gender, marital status, education level, income, and size of place all maintain their previous associations.

Model 4 includes the biblical literalism measures. As predicted, individuals who read the Bible literally are much more likely to oppose adoption by same-sex couples compared to all the other groups. Also as expected, even when controlling for views of the Bible, attendance at religious services and frequency of Bible reading are still negatively and significantly related to views toward same-sex adoption. With religious beliefs and practices accounted for in the model, there are now no significant differences between Evangelicals and every other religious tradition on support for same-sex adoption. Model 5 introduces a measure of political conservatism which is significantly and negatively associated with support for adoption by same-sex couples.

Model 6 includes a measure of whether respondents' believe homosexuality is innate (not a choice) and represents the full model. Believing homosexuality is innate is a robust and significant predictor of support for same-sex adoption. Regarding our variables of interest, in the full model, the odds of supporting same-sex adoption for those who interpret the Bible are 1.71 times greater than biblical literalists. Similarly, the odds of supporting same-sex adoption for those who believe the Bible contains errors or that it is a book full of history and legends are three times and 2.38 times greater, respectively. The odds of supporting adoption by same-sex 
couples for those who do not know what they believe about the Bible are 1.86 times greater than biblical literalists. Frequent attendance at religious services and frequent reading of sacred scriptures are each negatively and significantly associated with support of same-sex adoption. Frequency of prayer, however, is not. There continue to be no significant differences between conservative Protestants and every other religious tradition. Age, gender, marital status, education, income, and political ideology all maintain their previous associations.

Substantively, political conservatism $(\beta=-0.58)$ and believing homosexuality is innate ( $\beta$ $=0.39$ ) are the two strongest predictors in the full model. The standardized effect of the difference between biblical literalists and those who believe the Bible contains errors is the third strongest predictor $(\beta=0.20)$, along with the differences between biblical literalists and those who believe the Bible is an ancient book $(\beta=0.20)$. Age is the fourth strongest predictor $(\beta=-$ 0.18) followed by the difference between biblical literalists and those who interpret the Bible ( $\beta$ $=0.14)$ and marital status $(\beta=-0.14)$. Frequency of attending religious services $(\beta=-0.12)$ and reading sacred scriptures $(\beta=-0.11)$ are the next strongest predictors. These findings strongly suggest that, when predicting attitudes toward same-sex adoption, religious factors are quite important. Yet, as predicted in our fourth hypothesis, knowing where an individual worships (e.g., an Evangelical, Catholic, or Mainline church, or no church) is not as important as knowing how often they practice both publically and privately or the types of beliefs they hold.

\section{[TABLE 2 ABOUT HERE]}

Table 3 provides a more comprehensive examination of how the different views of the Bible relate to support for adoption by same-sex couples. The first column, model 4 , shows biblical literalists as the contrast category which is identical to model 4 from Table 2 and whose results were discussed above. Individuals who believe the Bible is perfectly true but it requires 
interpretation are the contrast category in model 5. The odds of supporting adoption for biblical literalists decrease 72 percent compared to interpreters. ${ }^{11}$ The odds for those who believe the Bible contains errors are 78 percent greater compared to interpreters. There are no significant differences between interpreters and those who believe the Bible is an ancient book, or those who do not know what they believe about the Bible. In model 6 those who believe the Bible contains errors are the contrast category. The odds of biblical literalists and interpreters supporting adoption by same-sex couples are 2.9 and 1.7 times less than those who believe the Bible contains errors. There are no significant differences between those who view the Bible as an ancient book, are undecided about their view of the Bible, and those who believe the Bible contains errors. In model 7 we find that the only significant difference for those who believe the Bible is an ancient book is with biblical literalists, whose odds are 2.3 times smaller. There are no significant differences for those who believe the Bible is an ancient book and interpreters, believing the Bible contains errors, and the undecided. Finally, model 8 focuses on those who are unsure of their view of the Bible. Regarding support for adoption by same-sex couples, there are no significant differences between this group and every other view of the Bible.

\section{[TABLE 3 ABOUT HERE]}

\section{Discussion and Conclusions}

The results from this analysis demonstrate religion's strong and multifaceted association with attitudes toward adoption by same-sex couples. While previous studies generally relied on over-aggregated measures of religious affiliation or used a single measure of religious behavior in worship service attendance, only by using a more complete array of religion measures does the true nature of the relationship between religion and same-sex adoption attitudes stand out. First, individuals who practice their religion more frequently by reading sacred scriptures or attending 
worship services are much more likely to oppose same-sex adoption. However, one private religious behavior, prayer, is not significantly associated with attitudes toward adoption by samesex couples. While it is through both public and private religious practice that individuals' plausibility structures are constructed and preserved and their attitudes toward adoption by samesex couples formed and sustained (Berger, 1967; Petersen \& Donnenwerth, 1998), not all religious behavior portends opposition toward adoption by same-sex couples. Accounting for this difference, religious service attendance and sacred text reading both expose adherents to traditional religious teachings on family relationships, and consequently, traditionalist schemas opposing homosexuality. In contrast, prayer is often done in private, and does not imply exposure to anti-homosexuality schemas. The non-significant effect of prayer frequency on support for same-sex adoption suggests that it is not religious devotion per se that inclines persons to oppose same-sex family forms, but inculcation with religio-cultural schemas that denounce such relationships. Biblical literalists, compared to those who believe the Bible should be interpreted, that it contains errors, that it is an ancient book of legends, or who are unsure of what they believe about the Bible, are also much more likely to oppose adoption by same-sex couples. Biblical literalists appear to be much more likely to apply passages concerning homosexuality to the present day (Burdette et al., 2005; Froese et al., 2008; Hill et al., 2004; Sherkat et al., 2010; Sherkat et al., 2011; Whitehead, 2010). Their schemas concerning homosexuality and the traditional family transpose onto the issue of adoption by same-sex couples.

This analysis also makes clear that once religious practice and religious belief are accounted for, the differences between Evangelical Protestants and the unaffiliated disappear. When considering attitudes toward adoption by same-sex couples, religious behavior and 
religious belief are most important while the differences between religious affiliations fade to the background. Our models suggest that the differences observed between Evangelical Protestants and the unaffiliated regarding support for same-sex families are due to their (obvious) underlying differences in religious behavior and Bible beliefs. The overall lack of effects of religious tradition could also be due to nominal affiliation patterns by those who claim to affiliate but are relatively inactive in the tradition. While religious traditions exhibit no significant differences in the attitudes individuals hold toward same-sex adoption in multivariate models, those influences are possibly channeled through the schemas, religious beliefs, and behaviors the religious traditions tend to encourage. Future analyses could utilize structural equation modeling to test if religious tradition has an indirect effect on attitudes toward same-sex adoption.

An even finer-grained analysis of Bible beliefs reveals more interesting findings. First, there is a definitive separation between biblical literalists and all other possible views of the Bible concerning views toward same-sex adoption. However, differences also exist between the other views of the Bible. Those who interpret the Bible are more likely to support same-sex adoption compared to biblical literalists, even though they still hold the Bible in very high regard, but are less likely to support adoption by same-sex couples compared to those who believe the Bible contains errors. Interpreters occupy a middle-ground between on this issue between biblical literalists and less traditional views of the Bible. These groups appear to approach this issue through different sets of schemas. This is an important finding when considering that over a third of Americans (34.5\%) support a view of the Bible that encourages interpretation, by far the largest group (see Table 1). Substantively, we find that in addition to Bible beliefs and behavior being the most important religious predictors of attitudes toward same-sex adoption, they are also among the most important predictors in the entire model. Future 
research examining attitudes toward adoption by same-sex couples must account for the multifaceted nature of religion. Only accounting for religious affiliation, or religious service attendance, may overlook the complex influence of religion as a whole.

A number of additional findings warrant discussion. First, political views are consistently the strongest predictor of attitudes toward same-sex adoption. This finding is in line with prior research that highlights the importance of political ideology on attitudes toward homosexuality generally, and same-sex unions specifically (Hill et al., 2004; Sherkat et al., 2011). The beliefs individuals have about the cause of homosexuality are also strongly associated with views of same-sex adoption. Various studies point out that believing homosexuality is a choice or an innate characteristic informs individuals' views toward the rights that should be afforded gays and lesbians (Haider-Markel \& Joslyn, 2008; Whitehead, 2010). However, attribution beliefs in past research on attitudes toward homosexuality and same-sex unions are consistently the strongest variables in the model (Haider-Markel \& Joslyn, 2008; Whitehead, 2010). When considering attitudes toward same-sex adoptions, however, attribution beliefs are second to political views. This suggests that an individual's political views influence her attitudes toward same-sex adoption more so than whether they believe sexuality is an innate characteristic or not.

The consistent negative association between marital status and support of adoption by same-sex couples stands out as well. Married individuals are much less likely than the unmarried to endorse the building of families by same-sex couples. Individuals with stakes in conformity and a vested interest in maintaining the status quo, which past theorists assume married individuals have, are less likely to favor any changes that might provide an alternative to their current situation (Burdette et al., 2005; Hill et al., 2004; McVeigh \& Diaz, 2009; Powell et al., 2010). Marriage could also operate as a type of plausibility structure where more traditional 
beliefs toward family life become solidified (Berger, 1969). The effects of age, gender, education, income, and region follow expectations drawn from past literature on attitudes toward same-sex sexuality, legal unions, and adoption (Andersen \& Fetner, 2008; Averett et al., 2009; Ryan et al., 2007; Sherkat et al., 2010; Sherkat et al., 2011; Whitehead, 2010).

Several limitations of the analysis must be mentioned. First, due to the cross-sectional nature of the 2010 BRS, causal direction cannot be determined. It may be that individuals' views toward same-sex adoption influence their interpretation of the Bible, or how often they attend religious services, or pray. Nevertheless, past research supports the theoretical progression we identify in this study that for most individuals, religious beliefs and practices occupy a central position in their lives that serves to influence their views on a number of issues. Second, the dependent variable does not distinguish between attitudes toward "gay couples" and "lesbian couples." Despite this weakness, public rhetoric surrounding gays and lesbians tends to focus on homosexuality as a whole. Social movements both supporting and opposing gay rights tend to either seek equality for both gays and lesbians or oppose them equally (Herek 2002). In this way, the dependent variable does measure a portion of this larger set of attitudes held by many (see footnote 4). Finally, future research could use structural equation models to tease out the relationships among the religious and political factors, which the step-wise multivariate models in this analysis are largely unable to do (see Sherkat et al. 2010, Sherkat et al. 2011).

Despite these limitations, this study advances the literature on attitudes toward adoption by same-sex couples in two important ways. First, it provides a comprehensive look at the multifaceted effects of religious belief, behavior, and affiliation. How individuals view the Bible and how often they practice their religion both publically and privately can tell researchers a great deal about how they will view same-sex adoption. Where a person worships matters much 
less. Second, this analysis shows that the effects of religious belief and behavior are among the strongest influences on a person's beliefs, net of all other possible effects. While political orientation and an individual's view of the cause of homosexuality exhibit the strongest associations with attitudes toward same-sex adoption, taken together, the combined effects of religion on an individual's views of adoption by same-sex couples is of central importance. As the legal recognition of various family structures are debated, religion will continue to influence and inform the attitudes of the public and the policy-makers. Understanding the multifaceted effect of religion on American adults is an essential element in comprehending their views toward adoption by same-sex couples.

Beyond the research implications of our study, the results presented here clarify for gay and lesbian couples seeking to adopt the sources of religious opposition. Our findings suggest that religious men and women tend to oppose the adoption of children by same-sex couples not because of religious affiliations or even personal religious devotion, but more likely because of greater inculcation with religio-cultural schemas (found in particular congregations and sacred Scriptures) that oppose same-sex relationships. Thus, for the gay community, attenuating this opposition would not necessarily require the denouncement of religious adherence per se, but rather an engagement with faith communities, providing countervailing narratives and encouraging such communities to embrace their deeper teachings about tolerance, equality, and love. Research on the importance of interpersonal contact with gays and lesbians for increasing support for gay rights suggests that engagement with faith communities may have positive results (Rosenfeld, 2007). 


\section{References}

Adamczyk, A., \& Pitt, C. (2009). Shaping attitudes about homosexuality: The role of religion and cultural context. Social Science Research, 38, 338-51.

Andersen, R., \& Fetner, T. (2008). Cohort differences in tolerance of homosexuality: Attitudinal change in Canada and the United States, 1981-2000. Public Opinion Quarterly, 72, 31130.

Averett, P., Strong-Blakeney, A., Nalavany, B., \& Ryan, S. (2011). Adoptive parents' attitudes towards gay and lesbian adoption. Journal of GLBT Family Studies, 7, 30-48.

Bader, C., Mencken, F., \& Froese, P. (2007). American piety 2005: Content, methods and selected results from the Baylor Religion Survey. Journal for the Scientific Study of Religion, 46, 447-63.

Baiocco, R., Argalia, M., \& Laghi, F. (2012). The desire to marry and attitudes toward same-sex family legalization in a sample of Italian lesbians and gay men. Journal of Family Issues, DOI: $10.1177 / 01925 X 12464872$.

Berger, P. (1967). The sacred canopy: Elements of a sociological theory of religion. New York, NY: Anchor Books.

Besen, Y., \& Zicklin, G. (2007). Young men, religion, and attitudes towards homosexuality. Journal of Men, Masculinities, and Spirituality, 1, 250-66.

Briggs, L. (2012). Somebody's children: The politics of transnational and transracial adoption. Durham, NC: Duke University Press.

Burdette, A., Ellison, C., \& Hill, T. (2005). Conservative Protestantism and tolerance toward homosexuals: An examination of potential mechanisms. Sociological Inquiry, 75, 177-96.

Clarke, V. (2001). What about the children? Arguments against lesbian and gay parenting. Women's Studies International Forum, 24, 555-70.

Denton, M. (2004). Gender and marital decision making: Negotiating religious ideology and 
practice. Social Forces, 82, 1151-80.

Dougherty, K., Johnson, B., \& Polson, E. (2007). Recovering the lost: Remeasuring U.S. religious affiliation. Journal for the Scientific Study of Religion, 46, 483-99.

Edgell, P., J. Gerteis, and D. Hartmann. (2006). Atheists as “other": Moral boundaries and cultural membership in American society. American Sociological Review, 71, 211-234.

Ellison, C., \& Musick, M. (1993). Southern intolerance: A fundamentalist effect? Social Forces, 72, 379-98.

Ellison, C., Wolfinger, N., \& Ramos-Wada, A. (2013). Attitudes toward marriage, divorce, cohabitation, and casual sex among working-age Latinos: Does religion matter? Journal of Family Issues 34, 295-322.

Frank, D., \& Mceneaney, E. (1999). The individualization of society and the liberalization of state policies on same-sex sexual relations, 1984-1995. Social Forces, 77, 911-43.

Froese, P., Bader, C., \& Smith, B. (2008). Political tolerance and god's wrath in the United States. Sociology of Religion, 69, 29-44.

Gallagher, S. (2003). Evangelical identity and gendered family life. New Brunswick, N.J.: Rutgers University Press.

Gallagher, S., \& Smith, C. (1999). Symbolic traditionalism and pragmatic egalitarianism: Contemporary evangelicals, family, and gender. Gender and Society, 13, 211-233.

Giddens, A. (1984). The Constitution of Society: Outline of the Theory of Structuration. Cambridge: Polity.

Haider-Markel, D., \& Joslyn, M. (2005). Attributions and the regulation of marriage: Considering the parallels between race and homosexuality. PS: Political Science and Politics, 38, 233-40.

Haider-Markel, D., \& Joslyn, M. (2008). Beliefs about the origins of homosexuality and support 
for gay rights: An empirical test of attribution theory. Public Opinion Quarterly, 72, 291310.

Herek, G. (2002). Gender gaps in public opinion about lesbians and gay men. The Public Opinion Quarterly, 66, 40-66.

Hill, T., Moulton, B., \& Burdette, A. (2004). Conservative Protestantism and attitudes toward homosexuality: Does political orientation mediate this relationship? Sociological Focus, $37,59-70$.

Hoffmann, J., \& Bartkowski, J. (2008). Gender, religious tradition and biblical literalism. Social Forces, 86, 1245-72.

Human Rights Campaign. (2013). Parenting laws: Joint adoption and Second parent adoption. http://www.hrc.org/files/ assets/resources/parenting_joint-adoption_062013.pdf. Accessed June 19, 2013.

Kite, M., \& Whitley, B. (1996). Sex differences in attitudes toward homosexual persons, behaviors, and civil rights: A meta-analysis. Personality and Social Psychology Bulletin, $22,336-53$.

Lambert, E. G., Ventura, L. A., Hall, D. E., \& Cluse-Tolar, T. (2006). College students' views on gay and lesbian issues. Journal of Homosexuality, 50, 1-30.

Lubbers, M., Jaspers, E., \& Ultee, W. (2009). Primary and secondary socialization impacts on support for same-sex marriage after legalization in the Netherlands. Journal of Family Issues, 30, 1714-1745.

McLeod, A. C., Crawford, I., \& Zechmeister, J. (1999). Heterosexual undergraduates' attitudes toward gay fathers and their children. Journal of Psychology and Human Sexuality, 11, 43-62.

McVeigh, R., \& Diaz, M. D. (2009). Voting to Ban Same-Sex Marriage: Interests, Values, and 
Communities. American Sociological Review, 74, 891-915.

Miller, A. and J. P. Hoffmann. (1999). The growing divisiveness: Culture wars or a war of words? Social Forces, 78, 721-745.

Olson, L. R., Cadge, C., Harrison J. T. (2006). Religion and public opinion about same-sex marriage. Social Science Quarterly, 87, 340-60.

Pampel, F. C. (2000). Logistic regression: A primer. Thousand Oaks, CA: Sage Publications.

Perry, S. L. (2013a). Multiracial church attendance and support for same-sex romantic and family relationships. Sociological Inquiry, 83, 259-85.

Perry, S. L. (2013b). Racial diversity, religion, and morality: Examining the moral views of multiracial church attendees. Review of Religious Research, 55, 355-76.

Petersen, L., \& Donnenwerth, G. (1998). Religion and declining support for traditional beliefs about gender roles and homosexual rights. Sociology of Religion, 59, 353-71.

Powell, B., Bolzendahl, C., Geist, C., \& Steelman, L. C. (2010). Counted out: Same-sex relations and American's definitions of family. New York, NY: Sage Foundation.

Rosenfeld, M. (2007). The age of independence: Interracial unions, same sex unions, and the changing American family. Cambridge, MA: Harvard University Press.

Rubin, D. B. (1987). Multiple imputation for nonresponse in surveys. New York: Wiley.

Ryan, S., Bedard, L., \& Gertz, M. (2004). Florida's gay adoption ban: What do Floridians think? University of Florida Journal of Law and Public Policy 15:261-283.

Ryan, S., Bedard, L., \& Gertz, M. (2007). The influence of gender on the placement of children with gay or lesbian adoptive parents. Journal of GLBT Family Studies, 3, 15-34.

Schulte, L., \& Battle, J. (2004). The relative importance of ethnicity and religion in predicting attitudes towards gays and lesbians. Journal of Homosexuality, 47, 127-42.

Sewell, William H. (2005). Logics of History: Social Theory and Social Transformations. 
Chicago, IL: University of Chicago Press.

Sherkat, D. (1998). Counterculture or continuity? Competing influences on baby boomers' religious orientations and participation. Social Forces, 76, 1087-115.

Sherkat, D., Mattias de Vries, K., \& Creek, S. (2010). Race, Religion, and Opposition to SameSex Marriage. Social Science Quarterly, 91, 80-98.

Sherkat, D., Powell-Williams, M., Maddox, G., \& Mattias de Vries, K. (2011). Religion, politics, and support for same-sex marriage in the United States, 1988-2008. Social Science Research, 40, 167-80.

Steensland, B., Park, J., Regnerus, M., Robinson, L., Wilcox, W. B., \& Woodberry, R. (2000). The measure of American religion: Toward improving the state of the art. Social Forces, 79, 291-318.

van den Akker, H., van der Ploeg, R., \& Scheeper, P. (2013). Disapproval of homosexuality: Comparative research on individual and national determinants of disapproval of homosexuality in 20 European countries. International Journal of Public Opinion Research, 25, 64-86.

Whitehead, A. L. (2010). Sacred rites and civil rights: Religion's effect on attitudes toward same-sex unions and the perceived cause of homosexuality. Social Science Quarterly, 91, $63-79$.

Whitehead, A. L. (2013). Religious organizations and homosexuality: The acceptance of gays and lesbians in American congregations. Review of Religious Research, 55, 297-317.

Whitehead, A. L., \& Baker, J. (2013). Homosexuality, religion, and science: Moral authority and the persistence of negative attitudes. Sociological Inquiry, 82, 487-509.

Wilson, R. (2004). A matter of conviction: Moral clashes over same-sex adoption. BYU Journal of Public Law, 22, 475-97. 
Table 1: Descriptive and Bivariate Statistics (MI Data)

\begin{tabular}{|c|c|c|c|c|}
\hline Variable & Description & $\begin{array}{c}\text { Mean or } \\
\%\end{array}$ & SD & $\begin{array}{c}\text { Correlation w/ } \\
\text { Same-Sex } \\
\text { Adoption }\end{array}$ \\
\hline $\begin{array}{l}\text { Support Same-Sex } \\
\text { Adoption }\end{array}$ & $1=$ Not wrong at all & $38.3 \%$ & -- & -- \\
\hline $\begin{array}{l}\text { Religious Service } \\
\text { Attendance }\end{array}$ & $\begin{array}{l}1=\text { Never to } 9=\text { Several times a } \\
\text { week }\end{array}$ & 4.09 & 2.97 & $-0.37 * * *$ \\
\hline $\begin{array}{l}\text { Freq. Reading Sacred } \\
\text { Scriptures }\end{array}$ & $\begin{array}{l}1=\text { Never to } 9=\text { Several times a } \\
\text { week }\end{array}$ & 4.35 & 3.08 & $-0.36 * * *$ \\
\hline Prayer Frequency & $\begin{array}{l}1=\text { Never to } 6=\text { Several times a } \\
\text { day }\end{array}$ & 4.02 & 1.82 & $-0.31 * * *$ \\
\hline Biblical Literalist $\dagger$ & $1=$ Biblical literalist & $20.9 \%$ & --- & $-0.30 * * *$ \\
\hline Biblical Interpretation & $1=$ Interpret Bible & $34.5 \%$ & --- & $-0.15 * * *$ \\
\hline Bible Contains Errors & $1=$ Bible contains errors & $12.5 \%$ & --- & $0.13 * * *$ \\
\hline Bible Ancient Book & $1=$ Bible full of legends & $23.8 \%$ & --- & $0.32 * * *$ \\
\hline Bible Undecided & $1=$ Don’t know & $8.2 \%$ & --- & $0.05^{*}$ \\
\hline Evangelical Protestant $\dagger$ & $1=$ Evangelical Protestant & $31.0 \%$ & --- & $-0.10 * * *$ \\
\hline Mainline Protestant & $1=$ Mainline Protestant & $24.9 \%$ & --- & -0.04 \\
\hline Black Protestant & $1=$ Black Protestant & $2.4 \%$ & --- & -0.01 \\
\hline Catholic & 1 = Catholic & $24.3 \%$ & --- & -0.04 \\
\hline Jewish & $1=$ Jewish & $1.6 \%$ & --- & 0.04 \\
\hline Other & $1=$ Other & $5.4 \%$ & --- & 0.00 \\
\hline No Religion & $1=$ No Religion & $10.3 \%$ & --- & $0.25 * * *$ \\
\hline Age & Age in years & 55.9 & 16.22 & $-0.19 * * *$ \\
\hline Female & $1=$ Female & $54.2 \%$ & --- & $0.07 * *$ \\
\hline Non-White & $1=$ Non-White & $5.3 \%$ & --- & 0.03 \\
\hline Married & $1=$ Married & $62.8 \%$ & --- & $-0.09 * * *$ \\
\hline Education & $\begin{array}{l}1=8^{\text {th }} \text { grade or less, } 7= \\
\text { postgraduate work/degree }\end{array}$ & 4.62 & 1.62 & $0.17 * * *$ \\
\hline Income & $\begin{array}{l}1=\$ 10,000 \text { or less to } 7= \\
\$ 150,000 \text { or more }\end{array}$ & 4.26 & 1.61 & $0.11 * * *$ \\
\hline South & $1=$ South & $35.2 \%$ & --- & $-0.10 * * *$ \\
\hline Urban & $1=$ Urban & $17.0 \%$ & --- & \\
\hline Politically Conservative & $\begin{array}{l}1=\text { Extremely Liberal to } 7= \\
\text { Extremely Conservative }\end{array}$ & 4.43 & 1.66 & $-0.59 * * *$ \\
\hline Homosexuality Innate & $1=$ Homosexuality Innate & $57.6 \%$ & --- & $0.44 * * *$ \\
\hline
\end{tabular}

Source: BRS (2010)

$\dagger$ Contrast Category

$* \mathrm{p}<.05 ; * * \mathrm{p}<.01 ; * * * \mathrm{p}<.001$ 
Table 2: Logistic Regression Analysis of Support for Same-Sex Adoption (MI Data)

\begin{tabular}{|c|c|c|c|c|c|c|c|c|c|c|c|c|}
\hline \multirow[b]{2}{*}{ Variables } & \multicolumn{2}{|c|}{ Model 1} & \multicolumn{2}{|c|}{ Model 2} & \multicolumn{2}{|c|}{ Model 3} & \multicolumn{2}{|c|}{ Model 4} & \multicolumn{2}{|c|}{ Model 5} & \multicolumn{2}{|c|}{ Model 6} \\
\hline & $\beta$ & OR & $\beta$ & OR & $\beta$ & OR & $\beta$ & OR & $\beta$ & OR & $\beta$ & OR \\
\hline Age & $-0.17 * * *$ & 0.98 & $-0.15 * * *$ & 0.98 & $-0.11 * *$ & 0.99 & $-0.13 * * *$ & 0.99 & $-0.14 * *$ & 0.98 & $-0.18 * * *$ & 0.98 \\
\hline Female & $0.11 * * *$ & 1.47 & $0.13 * * *$ & 1.58 & $0.18 * * *$ & 1.93 & $0.18 * * *$ & 1.92 & $0.12 * *$ & 1.53 & $0.10^{*}$ & 1.42 \\
\hline Non-White & 0.01 & --- & 0.02 & --- & 0.04 & --- & 0.05 & --- & -0.01 & --- & -0.00 & --- \\
\hline Married & $-0.19 * * *$ & 0.49 & $-0.18 * * *$ & 0.50 & $-0.16^{* * *}$ & 0.55 & $-0.16 * * *$ & 0.56 & $-0.13 * *$ & 0.62 & $-0.14 * *$ & 0.60 \\
\hline Education & $0.14 * * *$ & 1.17 & $0.15^{* * *}$ & 1.18 & $0.20 * * *$ & 1.25 & $0.15 * * *$ & 1.19 & $0.12 * *$ & 1.14 & $0.10 *$ & 1.12 \\
\hline Income & $0.15 * * *$ & 1.18 & $0.13 * *$ & 1.15 & $0.09 *$ & 1.11 & 0.07 & --- & $0.13 *$ & 1.16 & $0.12 *$ & 1.15 \\
\hline South & $-0.12 * * *$ & 0.64 & $-0.09 * *$ & 0.71 & -0.06 & --- & -0.05 & --- & -0.07 & --- & $-0.08 *$ & 0.73 \\
\hline Urban & $0.08 * *$ & 1.48 & $0.07 *$ & 1.43 & $0.07 *$ & 1.40 & $0.08 *$ & 1.44 & 0.06 & --- & 0.06 & --- \\
\hline \multicolumn{13}{|l|}{ Religious Affiliation $^{\text {a }}$} \\
\hline Mainline Protestant & & & 0.02 & --- & 0.01 & --- & -0.02 & --- & -0.01 & --- & -0.01 & --- \\
\hline Black Protestant & & & -0.01 & --- & 0.00 & --- & 0.00 & --- & 0.01 & --- & 0.03 & --- \\
\hline Catholic & & & 0.02 & --- & -0.01 & --- & -0.02 & --- & -0.02 & --- & -0.02 & --- \\
\hline Jewish & & & 0.04 & --- & 0.02 & --- & 0.02 & --- & 0.00 & --- & -0.00 & --- \\
\hline Other & & & 0.02 & --- & 0.02 & --- & -0.01 & --- & -0.01 & --- & 0.00 & --- \\
\hline No Religion & & & $0.27 * * *$ & 4.92 & $0.09 *$ & 1.75 & 0.06 & --- & 0.04 & --- & 0.05 & --- \\
\hline \multicolumn{13}{|l|}{ Religious Behavior } \\
\hline Attendance & & & & & $-0.22 * * *$ & 0.87 & $-0.15 * *$ & 0.91 & $-0.14 * *$ & 0.92 & $-0.11 *$ & 0.93 \\
\hline Reading sacred scriptures & & & & & $-0.26 * * *$ & 0.86 & $-0.19 * * *$ & 0.90 & $-0.16 * *$ & 0.91 & $-0.12 *$ & 1.03 \\
\hline Prayer & & & & & -0.05 & --- & -0.01 & --- & 0.04 & --- & 0.03 & --- \\
\hline \multicolumn{13}{|l|}{ Bible Beliefs $\uparrow$} \\
\hline Biblical Interpretation & & & & & & & $0.21 * * *$ & 2.26 & $0.20 * * *$ & 2.15 & $0.14 *$ & 1.71 \\
\hline Bible Contains Errors & & & & & & & $0.32 * * *$ & 5.67 & $0.25 * * *$ & 4.01 & $0.20 * * *$ & 3.03 \\
\hline Bible Ancient Book & & & & & & & $0.39 * * *$ & 5.21 & $0.27 * * *$ & 3.18 & $0.20 * *$ & 2.38 \\
\hline Bible Undecided & & & & & & & $0.18 * * *$ & 3.34 & $0.13 * *$ & 2.34 & $0.09 *$ & 1.86 \\
\hline \multicolumn{13}{|l|}{ Ideological Beliefs } \\
\hline Politically Conservative & & & & & & & & & $-0.62 * * *$ & 0.51 & $-0.58 * * *$ & 0.53 \\
\hline Homosexuality Innate & & & & & & & & & & & $0.39 * * *$ & 4.18 \\
\hline Intercept & -0.569 & & $-0.937 * *$ & & 0.070 & & $-1.008^{*}$ & & $1.919 * * *$ & & $1.280 *$ & \\
\hline $\mathrm{N}$ & 1,714 & & 1,714 & & 1,714 & & 1,714 & & 1,714 & & 1,714 & \\
\hline PRE & 0.073 & & 0.107 & & 0.184 & & 0.217 & & 0.331 & & 0.373 & \\
\hline
\end{tabular}

$* \mathrm{p}<.05 ; * * \mathrm{p}<.01 ; * * * \mathrm{p}<.001 ;$ two-tailed significance tests

$\beta=$ Standardized Coefficient

OR = Odds Ratio

${ }^{\mathrm{a}}$ Evangelical Protestant is contrast category

$\uparrow$ Biblical Literalist is contrast category 
Table 3: Odds Ratios Comparing Differences of Support for Adoption by Same-Sex Couples between Biblical Literalism Responses (MI Data)

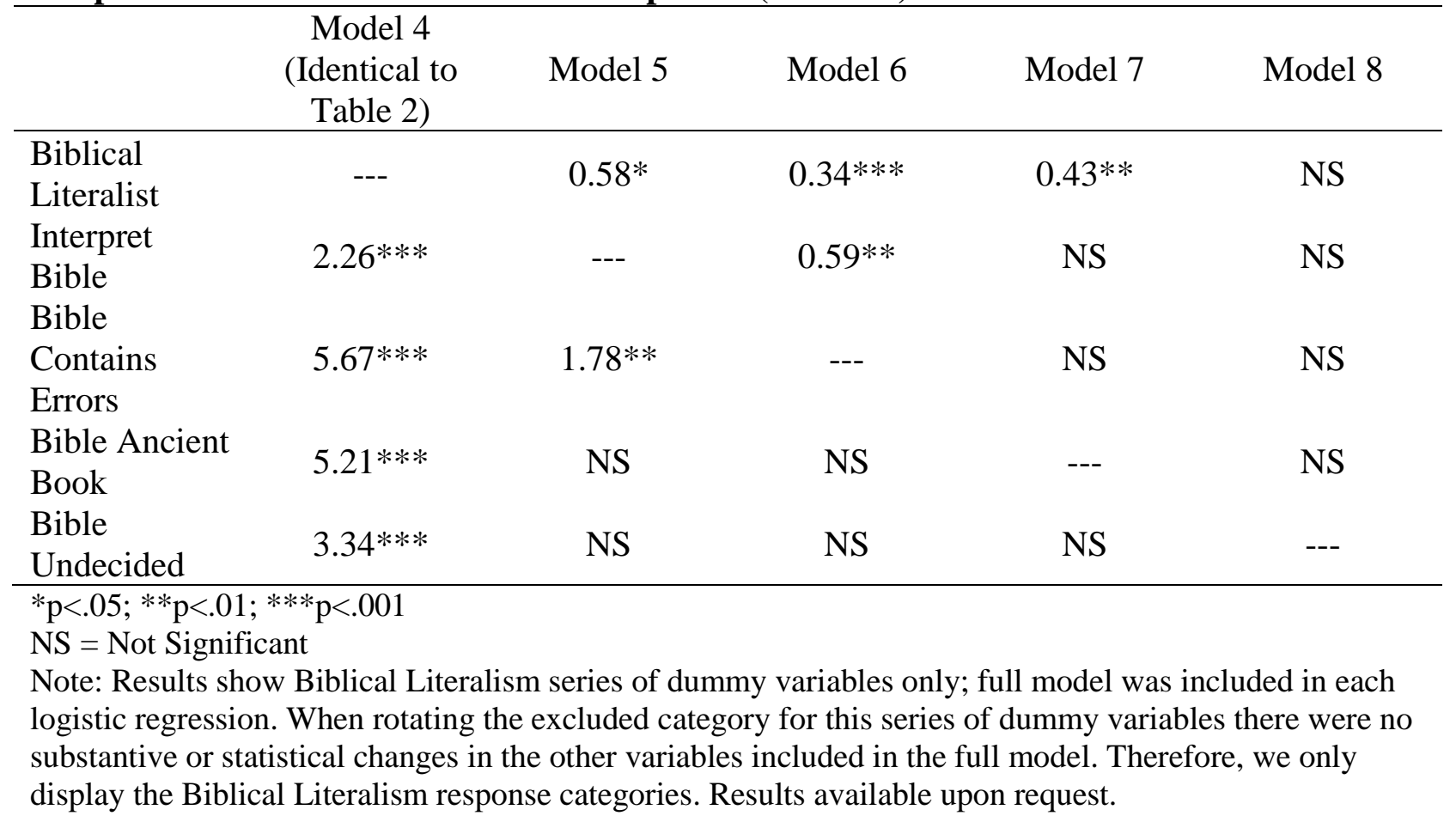


Endnotes:

${ }^{1}$ For example: Leviticus 18:22; Leviticus 20:13; Romans 1:26-27; 1 Corinthians 6:9-11.

${ }^{2}$ Same-sex romantic unions have been the focus of more explicit legal sanction than same-sex adoption. At the time of this writing, full marriage between same-sex partners is legal in 13 states and the District of Columbia, with civil unions being granted in another five states. A full 35 states prohibit full same-sex marriage by statute or in their constitutions, with 17 of these banning both same-sex marriage and civil unions. By contrast, only two states (Mississippi and Utah) have laws that explicitly prohibit same-sex couples from adopting. Twenty-one states and the District of Columbia allow for same-sex couples to jointly petition to adopt statewide while 18 states and the District of Columbia allow for second-parent adoption. A handful of other states, however, create obstacles for same-sex parents interested in adopting that hinge on the fact that they cannot be legally married in these states (Human Rights Campaign, 2013).

${ }^{3}$ For example, same-sex romantic relationships occur between social and legal peers who, under normal circumstances, both voluntarily agree to enter into a relationship. Same-sex adoption, by contrast, involves a different power dynamic between two adults and a minor child who (depending on their age at adoption) had little to no choice on her/his adoptive parents. Relatedly, because of the power dynamic, the direction of influence in same-sex adoption is more unilateral (parents $\rightarrow$ child(ren)) compared to influence in a same-sex romantic relationship (partner $\leftrightarrow$ partner). Lastly, while there is typically no developmental or financial need for an adult to be in a romantic relationship, minor children are vulnerable and in need of care and support for healthy development, and thus, require being placed in the care of legal guardians of some form.

${ }^{4}$ A weakness of this measure is that it asks for respondent's attitudes toward "homosexual couples" instead of either "gay couples" or "lesbian couples." Prior research shows that when asking about attitudes toward "homosexuality" the stronger negative reaction that gay men receive overwhelms the less negative reaction that lesbians generally receive, leading to more negative reactions to homosexuality in general (Herek, 2002; Kite \& Whitley, 1996). While specifically asking about "gay couples" or "lesbian couples" is ideal, Herek (2002) points out that public rhetoric commonly utilizes "homosexuality" with no distinction between gay men and lesbians. Likewise, most groups opposed to homosexuality do not distinguish between gay men and lesbians. The lack of distinction between gay men and lesbians is true for the gay movement as well; they desire equality for both. Herek (2002:42) points out that in the public discourse gay men and lesbians share a "common characteristic that makes them members of a distinct quasiethnic group with its own culture and political concerns." This means that while the question used cannot distinguish between attitudes toward gay men and lesbians, it does measure an aspect of the broader attitudes maintained by a majority of the public.

${ }^{5}$ The RELTRAD typology recommended by Steensland et al. (2000) categorizes Black Protestants using historically black denominations. However, doing so misses a great deal of variation within Black Protestantism, as Sherkat and colleagues show (2010). While we follow a wealth of past research that uses the RELTRAD typology, readers should interpret these results with caution.

${ }^{6}$ For details about religious tradition coding in the Baylor Religion Survey, see Dougherty, Johnson, and Polson (2007). 
${ }^{7}$ Due to the number of religion variables in the full model we performed collinearity diagnostics. Despite the correlation between the religion measures, multicollinearity does not appear to be adversely affecting the models. Also, the maximum likelihood estimation procedure used in the logistic regression models in these analyses is less susceptible to issues arising from multicollinearity compared to standard ordinary least squares techniques.

${ }^{8}$ The MI procedure generates five imputations using multiple Markov Chains based on all variables included in each model, resulting in an overall $\mathrm{N}$ of 8,570 (1,714 X 5). All results use the MI dataset. The correlations reported in Table 1 and all of the results reported in Tables 2 and 3 are from the MIANALYZE procedure in SAS. This procedure combines all of the results from each of the five imputations resulting in overall estimates, standard errors, and significance levels. The standardized coefficients and odds ratios for each model were calculated using these overall estimates. The Proportional Reduction in Error (PRE) reported in Table 2 for each model are the average of the PRE for each individual iteration.

${ }^{9}$ This analysis follows Pampel's (2000) assumption that the standard deviation of logit $(\mathrm{y})=$ 1.8138 .

${ }^{10}$ This analysis also tested for a host of moderating effects and interactions between the religion measures themselves, and between the religion measures and the socio-demographic control variables. However, no significant interactions were present. Further detail on which interactions were tested is available from the authors.

${ }^{11}$ In order to calculate the percent change in odds for the measures with negative odds ratios, 1 is divided by each ratio. This corrects for negative odds ratios being bounded between 0 and 1 . Thus, biblical literalists $=1 / 0.58=1.72$. 